\title{
Savings, Investment \& FDI Contribution To Malaysian Economic Growth In The Globalization Era
}

Kasim Mansur (E-mail: kmansur@ums.edu), University Malaysia Sabah, Malaysia Markos Mamalakis (E-mail: mamalaki@csd.uwm.edu), University of Wisconsin, USA Sidah Idris (Email: I_dah@ @otmail.com), University Malaysia Sabah, Malaysia

\begin{abstract}
What are the prospects and future of Foreign Direct Investment (FDI) in Malaysia now? Malaysia is undoubtedly a development success story. Throughout the post-independence period since 1957, Malaysia has enjoyed rapid economic growth with rising per capita income and price stability. Rising living standards, greater urbanization and access to health and education, and an improvement in the distribution of income have accompanied economic growth. Malaysian performance has been particularly remarkable after 1987 when the economy achieved above 7 per cent growth in seven consecutive years reaching virtual full employment in 1995. Malaysia now aspires to become a fully developed economy by 2020. This dramatic economic transformation has occurred against a background of massive shifts in the world economy as a result of increasing internationalization of production and trade. Foreign investment funds are returning to the market attracted by the corporate restructuring news and a belief that South East Asian stocks are generally undervalued. But FDI remains a big worry for the government and the last quarter figures cannot have helped. A recent survey by the Japanese Chamber of Trade and Industry in Malaysia claimed that the country no longer enjoyed a competitive advantage over its neighbors and that 22 per cent of Japanese companies operating in Malaysia were contemplating moving. In Penang more multinationals in the electronic sectors are planning to pull out of Malaysia in the next few months and relocate to China and Vietnam. So far these have all been in factories producing labor-intensive products. The main reason given for relocation is because of high labour costs. The purpose of this paper is to examine the Malaysian economic growth with emphasize on saving and investment in the context of globalization of the world economy. The main issues are: 1. Malaysian economic and Fiscal policy to stimulate economic growth. 2. The key policy shifts to guide the study of globalization and developmental implications to overall growth trends. 3. The role of foreign direct investment (FDI) and the implications of globalization for domestic employment and real wages, and poverty and income inequality.
\end{abstract}

From our analysis we found that economic development in Malaysia can be seen as a variant of the Solow model, in which savings, investment and capital accumulation are the major agents of growth. One aspect of the fast factor accumulation in this country is the important of FDI flows as a source of technology and management skills. FDI vis a vis savings and investment may have triggered export competitiveness by improving the technology, management and marketing of export industries.

Readers with comments or questions are encouraged to contact the authors via email. 


\subsection{Introduction}

1

$\mathrm{n}$ the economy as a whole, saving is the accumulation of assets, which lead to investment. Thus, saving and investment are interrelated. According to Solow, there is a direct connection between saving and investment to economic growth (Solow, 1956). In theory, higher savings leads to higher investment, which in turn leads to higher economic growth. The presumption is that higher saving precedes economic growth and higher savings causes economic growth. The belief in this contention leads to strong macroeconomic policy recommendations for economic development.

The rapid growth of those of the ASEAN countries and the Malaysian economy in particular in the context of macroeconomic stability has attracted international attention. The reasons for fast economic growth in the region, most economists agree that high rates of savings and investment in these countries have been a key factor in the economic success. Economic reforms in Malaysia, which have been transforming this country from resource-based to market-based economy, have drastically changed the pattern of savings and investment. The high rates of saving demand some explanation because they have been a significant factor in Malaysia's development. Some economic writings on this subject cited a number of reasons for Malaysia's exceptional savings performance. Among others are; unequal distribution of income, the traditional attitudes of the Chinese community toward saving, the welldeveloped system of social security combined with the custom of taking a job after retirement and the long record of price stability (Kasper \& Wolfgang, 1974).

Globalization involves a continuous adjustment process (Sieh L. M. L., 2000). Many countries around the world see their economic growth through increasing in international trade and capital investment. Each country perceives FDI becomes as an engine of growth in the globalization era. As for Malaysia, FDI inflows into Malaysia in the global economy are depending on various factors. The Malaysian government still is paying attention to technical and production sharing between FDI and local companies.

\subsection{Malaysia's Economic Growth}

The government savings have a positive and statistically significant impact on economic growth. The estimated coefficient implies that a 10 per cent point increase in the government saving-GDP ratio is associated with higher growth of 1.2 per cent points per year. Countries in which governments kept spending programs under control and realized larger surpluses on their current account budget grew substantially faster than those with small surpluses or deficits (Radelet et al., 1997).

Malaysia has long had a sustained record high economic growth. Between 1980 and 1988, Malaysia recorded an average annual rate of growth of GDP of about 5 per cent. In 1989 and 1991, average annual rate rose to 9 per cent (Halloway, 1991) and GDP contracted sharply by 6.7 per cent in 1998. In 2000, Malaysia's real GDP reached US $\$ 55.07$ billion and recording a high growth of 8.5 per cent as compared to 5.8 per cent growth achieve in 1999. However in 2001 GDP growth rate improved to 8.5 per cent and it is expected GDP for 2002 will be around 4.5 per cent. While growth was supported by strong external demand, it was rising private consumption and the strong revival in domestic investment was the main contributor to economic growth. Government's policy strategies to diversify the Malaysian economic structure continue in the year 2002 to further deepen and widen the industrial base, and to enhance the development of the services sector as a second engine of economic growth.

\subsection{Savings and Investment}

High savings and investment ratios compared to other developing countries have accompanied Malaysia high rate of economic growth. In 1970-1981, domestic savings in Malaysia average 25 per cent of the GDP, but in 1990 Malaysia's savings ratio reached 34.8 percent and higher than South Korea and Taiwan. Gross domestic investment averaged 26.1 per cent of the GDP between 1970 and 1981. Gross domestic investment reached an average of 34 per cent of GDP on 1981 and 1984, but fell to an average of 26 percent in the latter half of the 1980s (World Bank, 1990). However, Malaysia's records of savings and investment performance remain one of the best amongst less developed countries. 
In the 1950s through 1970s, Malaysia's gross national saving were 22.5 per cent and become the highest among the rest of the Asian countries. In 1991, Malaysia stands out as having a high savings rate, which was 30.6 per cent as a proportion of GDP. This has been due to among other factors, financial deregulation leading to positive real rate of interest, macroeconomics stability leading to relatively low rates of inflation and political stability (Chandavarkar, 1993). Between 1991 and 1998, savings as a proportion of GDP was increased from 30.7 percent to 38.8 percent. By 2000, Malaysia's saving and investments were significantly remaining strong, worth RM 31.9 billion. In 2001, the government reentered international debt markets with a 10 years US\$1 billion bond issue, with a 7.5 per cent coupon rate and yielding 7.7 per cent. The government plans to use proceeds to fund infrastructure projects to boost slowing economic growth. In response to the economic downturn of 2001, the government introduced US\$790 million stimulus package, which is equivalent to about 1per cent of GDP. This amount was in addition to the RM28.8 billion (U.S.\$7.58 billion) under the 2001 budget.

For the country to compete in the global market, the Malaysian Government is now implementing her policy by attracting more domestic and foreign investment into this country. The improvement in global business would be effected on Malaysia's investment through high level of approved manufacturing investment in Malaysia (Public Bank Economic Review, 2002). The government took the level of approved investment as the target in Second Industrial Master Plan (1996-2005) with sustained domestic investment and increase foreign investment in the non-resource-based industries.

TABLE 1: Total Malaysia Approved Investment Project in Manufacturing Sector (2001)

\begin{tabular}{|l|c|c|c|c|}
\hline \multicolumn{1}{|c|}{ Industries } & Total project & Amount & $\begin{array}{c}\text { Domestic investment RM } \\
\text { billion /(\%) }\end{array}$ & $\begin{array}{c}\text { Foreign investment RM } \\
\text { billion /(\%) }\end{array}$ \\
\hline Resource-based & 352 & RM 10.7 & RM 4.2/66.0\% & RM $6.5 / 35.6 \%$ \\
\hline Non-resource-based & 461 & RM 14.0 & RM $2.2 / 34.0 \%$ & $\mathrm{RM} 11.8 / 64.4 \%$ \\
\hline
\end{tabular}

Source: Second Industrial Master Plan, 1996-2005

\subsection{Policies that Promoted Savings}

Malaysia's saving rate was at 39.5 per cent of GNP in 2000 and remains one of the highest in the world. At the end of 2000, Malaysia's total foreign debt was US $\$ 41.3$ billion contributed 51 per cent to GNP but remains easily manageable. Malaysia had more than sufficient foreign exchange reserves (US \$25.9 billion) until the end of May 2001 to cover maturing short-term obligations. Private domestic debt was significantly larger, which is accounting for 134 per cent of GNP at year-end 2000.

TABLE 2: Malaysia: Operations of the Employee Provident Fund (EPF)

\begin{tabular}{|l|c|c|c|c|c|}
\hline & $\mathbf{1 9 9 6}$ & $\mathbf{1 9 9 7}$ & $\mathbf{1 9 9 8}$ & $\mathbf{1 9 9 9}$ & $\mathbf{2 0 0 0}$ \\
\hline Receipts & 21131 & 22989 & 24173 & 25824 & 27430 \\
Contributions & 12899 & 14614 & 14758 & 15203 & 20190 \\
Investment income & 8137 & 8331 & 9370 & 10572 & 17582 \\
Other & 95 & 44 & 45 & 49 & 54 \\
\hline Expenditure & 3980 & 5916 & 8635 & 7357 & 9991 \\
Withdrawals & 3768 & 5679 & 8441 & 7112 & 4484 \\
Operating expenditure & 212 & 237 & 194 & 245 & 878 \\
\hline Balance & 17151 & 17073 & 15538 & 18467 & 18484 \\
(In per cent of GDP) & 6.8 & 6.1 & 5.5 & 6.5 & \\
\hline Holding of government securities & 38754 & 38068 & 45670 & 51813 & 61765 \\
(Changes in the holding of government securities) & -398 & -686 & 7602 & 6143 & 6732 \\
Registered employees (in thousands) & 8050 & 8357 & 8513 & 9532 & n.a \\
Registered employers (in thousands) & 276 & 295 & 298 & 303 & n.a \\
\hline
\end{tabular}

Source: IMF, 2001 
Malaysia has well-developed, mandatory pension plan. The impact of these plans on aggregate savings depends on the degree to which they substitute for voluntary savings. In Malaysia, the largest single savings institution is known as the Employee Provident Fund (EPF), which accounts for approximately 20 percent of total employee's income. The Malaysian government cut the required contribution by employees into the national retirement fund (EPF) 11 per cent of wages and salaries. However, the investment trusts of the Permodalan National Berhad (PNB) and the Islamic savings institutions also attract a further large proportion of these savings (Adam et. al., 1995). The government has also established Danamodal - a special purpose vehicle to recapitalize financial institutions. For the moment, Danamodal has injected RM 7.1 billion (US $\$ 1.9$ billion) into 10 banking institutions.

A private Postal Savings Institution under Pos Malaysia Berhad (then Postal Department of Malaysia) was established to encourage savings. This institution was established to attract small savers. Postal Savings System offered small savers greater security and lower transaction costs than the private sector. This system were therefore particularly effective in attracting the formal financial sector as well as the saving of low-income and rural households. Like in most of the Asian countries, Malaysia has also granted tax-exempt status to the interest income generated from postal savings during long periods.

In Malaysia as well as in Singapore, postal savings also accounted for a large proportion of domestic deposits. The government separated the management of saving system from the post office in the early 1970s when the proportion of the postal savings in total savings declined, evidently because postal employees were not enthusiastic promoters of savings.

TABLE 3: Malaysia: Outlines Of Major Policy Implementation Financing Institutions

\begin{tabular}{|l|l|l|l|l|}
\hline \multicolumn{1}{|c|}{$\begin{array}{c}\text { Name of } \\
\text { Institution }\end{array}$} & $\begin{array}{l}\text { Total Assets } \\
\text { (As of 2000) }\end{array}$ & Market share & Sources of Funds & Use of Funds \\
\hline $\begin{array}{l}\text { Malaysia } \\
\text { Industrial } \\
\text { Corporation } \\
\text { 1966) }\end{array}$ & $\$ 2401$ million & $\begin{array}{c}\text { Half } \\
\text { Government } \\
\text { Half Private }\end{array}$ & $\begin{array}{l}\text { Borrowing from the } \\
\text { govern-ment and Central } \\
\text { Bank }\end{array}$ & $\begin{array}{l}\text { Finance for industry in particular small } \\
\text { and medium size enterprises in the } \\
\text { food, metals, lumber, and rubber } \\
\text { industries }\end{array}$ \\
\hline $\begin{array}{l}\text { Development } \\
\text { Bank of Malaysia }\end{array}$ & $\$ 800$ million & $\begin{array}{l}2.6 \text { percent } \\
\text { (Government } \\
98 \text { percent) }\end{array}$ & $\begin{array}{l}\text { Borrowing from the } \\
\text { govern-ment }\end{array}$ & $\begin{array}{l}\text { Medium to long-term finance and } \\
\text { guarantees for bumiputera enterprises, } \\
\text { terms: 1 to 5 years for working capital }\end{array}$ \\
\hline $\begin{array}{l}\text { Industrial Bank of } \\
\text { Malaysia (1979) }\end{array}$ & $\$ 129$ million & Government & $\begin{array}{l}\text { Borrowing from the } \\
\text { government and Central } \\
\text { Bank Government } \\
\text { Subscription foreign bonds }\end{array}$ & $\begin{array}{l}\text { Finance for shipbuilding and shipping } \\
\text { industry }\end{array}$ \\
\hline $\begin{array}{l}\text { Sabah } \\
\text { Development } \\
\text { Bank (1978) }\end{array}$ & $\$ 826$ million \\
\hline $\begin{array}{l}\text { Agriculture Bank } \\
\text { of Malaysia (1969) }\end{array}$ & Government & $\begin{array}{l}\text { Government subscription, } \\
\text { borrowing form } \\
\text { government Institutions }\end{array}$ & $\begin{array}{l}\text { Finance for the promotion of } \\
\text { commerce and industry in Sabah and } \\
\text { Sarawak }\end{array}$ \\
\hline
\end{tabular}

Source: Central Bank of Malaysia

Gross national saving rose by 1.5 percentage points to 38.8 per cent of GDP in 1998 , as rising private saving offset a marked decline in public sector savings. Mounting uncertainty over direction of the economy as well as the negative wealth effect from the sharp fall in asset prices contributed to a decline in consumption and a rise in the saving rate of household. Public saving fell markedly, largely reflecting the automatic impact of the economic cycle on the budget.

The Malaysian government has created a wide range of financial institutions to fill perceived gaps to the types of credit provided by private entities. These banks addressed the need for long-term credit for industry by creating development banks (see table 3). Malaysian development financial institutions accounted for 2.9 per cent of 
the assets of the financial systems in 1980s. According to World Report, overall performance of the development financial institutions in Asian as well as in Latin America, and Sub-Saharan Africa were unsuccessful because of low payment rates (World Report, 1995). By January 2001, total amount outstanding had been reduced to RM3.7 billion (US\$974 million), after eight banks made partial or full repayments. A third institution, the Corporate Debt Restructuring Committee (CDRC) was set up to facilitate voluntary corporate debt restructuring between creditors and viable debtors. On March 2001, the CDRC had received 75 applications for debt restructuring involving debts of RM47.2 billion (US $\$ 12.4$ billion) and 33 cases involving RM25.8 billion (US $\$ 6.8$ billion) were resolved.

Insurance companies were included as a savings institution in non-bank financial institutions. The Insurance industry was regulated and supervised by the Ministry of Finance. The industry has recorded high growth in insurance fund assets or generally in savings industry. The Malaysian government played a role in controlling foreign share in the insurance industry to protect domestic players. But like the banking industry, government policy on insurance sectors will be relaxed. Perhaps this will provide an opportunity for foreign reinsures to enter Malaysia by 2003 .

In Malaysia, mutual funds and research houses became prominent during the 1900s when Malaysia's economy and stock market were booming (Sieh L. M. L, 2000). The Malaysian government restrictions on the activities of foreign stockbrokers and fund managers are meant to protect domestic fund management and research companies, which is still in its early growth stage.

The government developed a corporate bond rating company in January 1991 after the takeoff. According to the World Bank Report, bond and equity market played a relatively small role in Asian finance. The Malaysian government has taken considerable steps by increasingly issuing corporate bonds to draw on the strength of worldwide reputations and access to international financial market. Recognizing to the value of a healthy bond market, Malaysia has introduced a corporate bond-rating agency (World Bank, 1995).

TABLE 4: Net Financing Sources Of Non-Financial Corporations In Selected Asian Economies

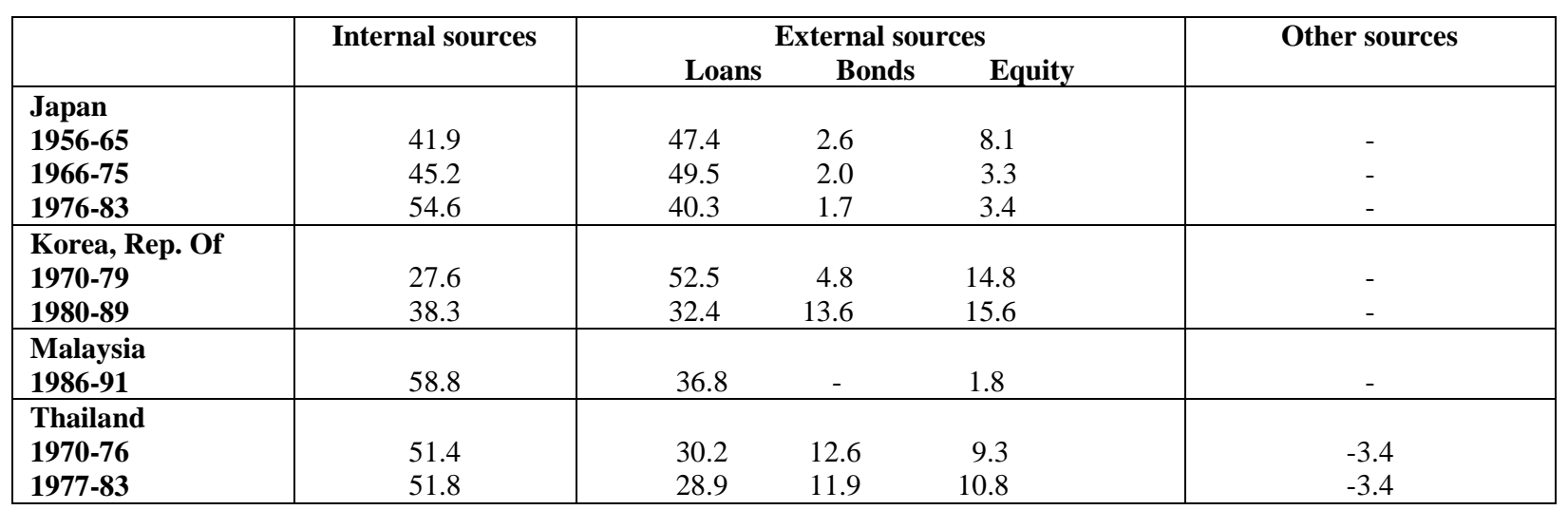

Source: World Bank, 1995

Before the Asian crisis of late 1997, government liberalizing rules in the banking and finance sector have attracted FDI into the country. These rules enable easier fund management by investors especially to the prevailing freedom of exchange and of fund transfers to manage risks when importing or exporting. However, during the economic crisis, the Malaysian government took a step by pegging the Ringgit exchange rate on RM3.80 to one US dollar. The policy will help Malaysia ensure that domestic and external development of Malaysian economic remains consistent. The exchange rate policy is to maintain the stability of planning and investment decision in Malaysia. 


\subsection{Policies That Promoted Investment}

In general, policies to promote investment in Malaysia can be grouped into three broad categories. First, as the economies have matured, policymakers have gradually increased their attention to the creation and improvement of bond and equity markets. However, while these markets are playing an increasing important role, they are not generally a key factor in mobilizing investment when the company was in takeoff stage. Second, Malaysia among the countries in Asia have created development banks to ease constraints in long-term capital markets, as well as specialized institutions to provide financing to agriculture and small-medium size enterprises. Third, Malaysian government as well as other Asian governments has encouraged investment with a wide array of other mechanisms designed to increase the attractiveness of private investment.

Since 1971, the first year of the second plans, the growth in public investment has been sharp and sustained. In constant prices, fixed public investment more than double between 1970 and 1976. It grew at an average annual rate of more than 15 percent. The expansions reflected the goals of the NEP and significantly contributed to the growth rate and have a direct impact on poverty eradication.

During 1987 since independence, Malaysian economic for the first time experienced negative growth. After mid 1988 to mid 1997, the Malaysian economy stated to show sign of improvement and rapid growth, which annual growth averaged more than 7 per cent. The Malaysian government adopted various reforms to draw capital formations such as the establishment of the second stock market in 1988 and the absorption of the Bumiputera Security Exchange into the Kuala Lumpur Stock Exchange (KLSE). The Malaysian government also took a step with permission for financial institutions such as banks to invest in security houses in 1986, and raising the maximum share of foreign security houses investment in Malaysian Security Houses from 30 per cent in 1986 to 49 percent in 1988. The government also actively pushed for the listing of privatized firms.

In addition to high savings rates, Malaysia has also registered high investment ratio (World Bank, 1993). The evaluation of investment, savings, and exports in Malaysia during the past three decades corresponds to closely to this pattern of the rapid sustainable growth. Malaysia's gross domestic investment began accelerated and accumulated in the 1950s and rose continuously until 1990s. However, in 1998 due to a sharp contraction in gross domestic investment, savings on the other hand shows some modest rise and in excess over investment.

The expansion in private investment also was substantial after late 1960s. During 1969 to 1974, there was substantial increased, estimated at 120 per cent to 150 per cent in real fixed investment. In relation to GNP, private fixed investment reached a peak of 19 per cent in 1974. But the decline was sharp, as private investment fell in absolute terms by about a fifth between 1974 and 1976. According to Hassan, due to lack of official data, the decline between 1974 and 1976 was considerably greater, perhaps as much as 50 per cent greater for manufacturing investment than all private investment (Hassan, P. et. al, 1980)

In 1990 to 1995, shows a sharp increased in gross domestic investment and followed by a steady growth between 1995 and 1997, and eventually fell sharply in 1997. This phenomenon was due to the Asian economic crisis in July 1997, which includes the completion of most of large infrastructure projects and the slow down in implementation of existing projects. Gross domestic investment fell sharply from 42.5 per cent of GDP in 1997 to 25.8 percent of GDP in 1998, capturing a fall in private investment to less than half the level of the previous years.

The Promotion of Investment Act 1986 and the Industrial Coordination Act 1975 are involve in government regulations to promoting FDI. In terms of government regulation, a foreign partner is allowed to hold a maximum of 30\% stake in Malaysian companies and $70 \%$ in local fund management companies whose working with both local and foreign clients. Stock broking companies have been allowed to hold as high as 49 per cent ownership. In 1998, the government has allowed foreign investors engaged in telecommunications to own up to a maximum of $61 \%$ of equity through diversture and 49 per cent through dilution of share after five years of operation. 


\subsection{Foreign Direct Investment (FDI) and Economic Growth}

During the period of 1960 to 1965 , manufacturing in Malaysia expanded significantly contributed 12.2 per cent growth per year. At this time, Malaysia attracted FDI to invest into Malaysia with established wholly owned rather than joint venture with controlled 30 per cent of total investment in fixed assets. In 1968, government encouraged FDI to invest into Malaysia with export-oriented industries. FDI contribute to created jobs for local people through labor-incentive industries. Investors also selected Malaysia as their location because of market consideration and Malaysian natural resources.

The Malaysian government has established Malaysia Industrial Development Authority (MIDA) under the Federal Industrial Development Act, 1965 to promoting foreign investment (FDI). The main functions of MIDA are to handle the task of promoting industrial and investment in Malaysia with establishing direct relation to Ministry of International Trade and Industry (MITI) and in implementing government role and policy to international trade and foreign investment.

The Malaysian government encourages FDI particularly in export-oriented manufacturing and high-tech industries. Base on Malaysia Economic Report 1997/1998, the largest contributor to Malaysia's manufactured exports was the electronic and electrical product, followed by textile industry, food, beverage and tobacco, wood and chemicals industries. One of FDI attractiveness into Malaysia is through Multimedia Super Corridor (MSC) project. However, MSC does not actively seek FDI in service or agriculture and construction industries. Foreign companies that are granted Multimedia Super Corridor (MSC) status are also permitted 100\% ownership.

The Malaysian government encourage the industries to participate in approved industrial adjustment programs especially in the purpose to improve industrial technology, increasing productivity and to enhance the use of natural resources and management efficiency in wood-based, machinery and engineering sectors. Otherwise, government also provided other incentives to attract domestic and foreign investment by implementing incentives for small-scale companies, large companies and the vendors. The government also provided an incentive for promoting local branded product by encouraging buying Malaysian products that included in government expenditure effective from year 1998.

\subsection{Exports}

Over the period of fifty-one years (1951-2001), the export orientation of Malaysia has gone up quite markedly. This is consistence with the ADB empirical work that there is strong correlation between the rate of growth of exports and real GDP. In 1980 and 1990, Malaysia's exports in comparison to Newly Industrial Economies (NIEs) country (South Korea, Taiwan, Hong Kong, and Singapore), Malaysia recorded the highest. Over the same period, export growth rates ranged from 15.5 per cent in the NIEs to 7 percent in ASEAN.

TABLE 5: Malaysia's Export and Import Growth Between 1996- 2000

\begin{tabular}{|l|c|c|c|c|c|c|c|c|c|c|c|}
\hline & $\mathbf{1 9 9 6}$ & $\mathbf{1 9 9 7}$ & $\mathbf{1 9 9 8}$ & $\mathbf{1 9 9 9}$ & $\mathbf{2 0 0 0}$ & $\mathbf{1 9 9 6}$ & $\mathbf{1 9 9 7}$ & $\mathbf{1 9 9 8}$ & $\mathbf{1 9 9 9}$ & $\mathbf{2 0 0 0}$ \\
\hline & \multicolumn{9}{|c|}{ Exports } \\
\hline ASEAN & 27.9 & 27.5 & 23.9 & 23.5 & 26.2 & 19.9 & 20.3 & 22.6 & 23.4 & 23.9 \\
Singapore & 20.4 & 20.1 & 17.0 & 16.5 & 18.4 & 13.4 & 13.1 & 13.6 & 14.0 & 14.3 \\
Japan & 13.4 & 12.4 & 10.6 & 11.6 & 13.1 & 24.5 & 22.0 & 19.6 & 20.8 & 21.1 \\
India & 1.5 & 1.5 & 2.4 & 2.4 & 2.0 & 0.9 & 1.0 & 0.8 & 0.8 & 0.9 & 2.0 \\
Australia & 1.6 & 1.7 & 2.3 & 2.4 & 2.5 & 2.8 & 2.5 & 2.2 & 2.3 & 1.7 & 10.8 \\
EU & 13.7 & 14.5 & 16.2 & 15.7 & 13.7 & 14.4 & 14.1 & 11.9 & 11.7 & 16.6 \\
U.Stated & 18.2 & 18.6 & 21.7 & 21.9 & 20.5 & 15.5 & 16.8 & 19.6 & 17.4 & 16.6 \\
Other & 23.7 & 23.8 & 23.0 & 22.6 & 22.0 & 22.2 & 23.4 & 23.3 & 23.6 & 24.7 \\
Total & 100 & 100 & 100 & 100 & 100 & 100 & 100 & 100 & 100 & 100 \\
\hline
\end{tabular}

Source: IMF, 2001 
TABLE 6: Malaysia's Trade 2000- Jan 2002

\begin{tabular}{|l|l|l|l|l|l|l|}
\hline YEAR/ PERIOD & \multicolumn{1}{|c|}{$\begin{array}{c}\text { Value } \\
\text { (RM Million) }\end{array}$} & $\begin{array}{c}\text { Growth } \\
\text { rate (\%) }\end{array}$ & $\begin{array}{c}\text { Value } \\
\text { (RM Million) }\end{array}$ & $\begin{array}{c}\text { Growth } \\
\text { rate (\%) }\end{array}$ & $\begin{array}{c}\text { Value } \\
\text { (RM Million) }\end{array}$ & $\begin{array}{c}\text { Growth } \\
\text { rate (\%) }\end{array}$ \\
\hline $\mathbf{2 0 0 0}$ (Jan-Dec) & $373,270.32$ & & $311,458.88$ & & $61,811.44$ & \\
\hline $\mathbf{2 0 0 1}$ (Jan-Dec) & $334,420.02$ & $(10.41)$ & $280,691.10$ & $(9.88)$ & $53,728.93$ & $(13.08)$ \\
\hline $\mathbf{2 0 0 1}$ (Jan) & $28,092.66$ & & $25,059.05$ & & $3,033.60$ & \\
\hline 2002 (Jan) & $27,499.85$ & $(2.11)$ & $23,094.08$ & $(7.84)$ & $4,405.77$ & 45.23 \\
\hline
\end{tabular}

Source: Department of Statistics, Malaysia

South East Asian Countries has become a major destination for the FDI. Between 1967 and 1978, South East Asian Countries experienced the fastest rate of growth of FDI in developing countries. Between 1970s and 1990s, the trend of the FDI surged into East Asian developing countries continued. Since 1980s FDI continued to enter into this region, in absolute value rising to $\$ 44$ billion in 1994 and export have grown at over 10 per cent a year. Total trade between developing countries in the region has risen from 25 per cent to 40 per cent of their total trade since 1980 (Asian Development Bank, 1996). These countries did not rely on foreign borrowing as source of saving as they have a very high savings rates, that almost matched or more than matched their very high rates of capital formation.

The Asia-Pacific region has emerged as one of the world's top trading regions, its share of world trade increased from 14.6 percent in 1980 to 22.3 percent in 1992. However, at the time of the Asian financial crisis, Malaysia, as well as other affected Asian countries has experienced a sharp declined in export prices. This has contributed to the contraction in the nominal dollar value of exports from the affected countries. Types of goods that have been affected include electronics and electrical (E\&E), machinery and equipment, computer equipment, office machines, and transportation equipment.

According to Asian Development Bank (ADB, 2000), FDI has played an important role in the economic development of Southeast and East Asia. In the Asian Development Outlook (ADO) 1999, the ADB points out that FDI has led to a transfer of production of labor intensive products and exports from high wage source nations to lower wage host nations. Export oriented manufacturing industries has been the main theme of Malaysian economic policy, because it is the key to growth strategy in which GNP growth is maximized by the growth of investment. The FDI pattern is consistent with the objectives of the NEP formulated by the government. According to the Institute of Strategic and International Studies of Malaysia, this country is still trying to find a strong, clear position on industrialization (ISIS, 2000).

Malaysian current account surplus remained strongly positive in 2000 at RM31.9 billion (US\$8.4 billion) but lower than RM47.9 billion (US $\$ 12.6$ billion) surplus in 1999 . The reduced surplus was due primarily to a smaller surplus in the merchandise trade account and higher deficits in services and transfers. Exports rose 17 per cent year-on-year in 2000 but merchandise imports increased at an even more rapid pace of 26.2 per cent. The continuously trade surplus in the face of declining exports as a result of rapidly declining imports of intermediate components used in the manufacture of Malaysia's electronics exports. In end of 2001, total domestic demand in current prices is increased 5.5 per cent through the improvement of export earning and fiscal stimulus in a way to boost Malaysian economy in 2002. The high improvement in Malaysian economy is a contribution from increasing in private consumption by 5.5 per cent and strong growth in private investment. For the fifty-first consecutive month, Malaysia recorded a trade surplus in January 2002, amounting to RM4.4 billion, compared to RM4.8 billion in December 2001.

The increasing growth in exports of 6 per cent largely given by manufactured goods. The electrical and electronic (E\&E) goods largely contribute to Malaysian export goods as a respond to an increase in global electronics demand. Import of intermediate goods and non-factor services to Malaysia also give an upward swing of 
5.9 per cent. Malaysia's current account is expected to register a higher surplus, an increase to 8.4 percent in 2002 compared to 7.9 percent of GNP or RM25, 070 million in 2001.

\subsection{Policies to Increase the Attractiveness of Investment}

Besides fostering a climate conducive to promote investment as mentioned above, the Malaysian government has also introduced variety of mechanisms to make private investment more attractive. Four highly specific mechanisms used in Malaysia as well as in Asian countries to encourage investment are; low relative prices for capital goods; risk sharing; controls on capital outflows; and mild financial repression. The most frequently used policy mechanism to attract and to promote private foreign investment is tax policy.

The Malaysian government has employed a wide variety of tax policies to encourage investment by raising the retained earnings of companies. Besides that, Malaysian Government also used low relative price policy for capital goods to attract foreign investment. In this case, tax, tariff, and exchange rate policies influenced the incoming of the capital goods to the country.

TABLE 7: Malaysian Incentives for Manufacturers

\begin{tabular}{|l|l|}
\hline \multicolumn{1}{|c|}{ Type of incentives } & \multicolumn{1}{c|}{ Purposes } \\
\hline Pioneer status & $\begin{array}{l}\text { New industries can receive full or partial tax exemption for five to ten years depending } \\
\text { on the type of products. }\end{array}$ \\
\hline Investment tax allowance (ITA) & $\begin{array}{l}\text { Up to } 60 \% \text { of capital expenditure incurred during the first five years of project } \\
\text { commencement }\end{array}$ \\
\hline Reinvestment allowance & $60 \%$ of capital expenditures to expand, modernize or diversify an existing facility \\
\hline Export Credit Refinancing (ECR) & Short-term commercial credit for pre and post-shipment \\
\hline Export allowance & Deduction of 5 percent on FOB value of export sales \\
\hline Export Credit Insurance & Double deduction to insurance company which is approved by the Ministry of Finance \\
\hline Export promotion & Double deduction for certain qualifying expenditures \\
\hline Infrastructure allowance (IA) & 100 per cent for capital expenditure on infrastructure (available until October 1998) \\
\hline $\begin{array}{l}\text { Incentives for Research and } \\
\text { Development }\end{array}$ & $\begin{array}{l}\text { Include 5 year tax holiday and permission to carry tax-relief period losses forward to } \\
\text { the taxable period }\end{array}$ \\
\hline Incentives for training & Double deduction for approved training \\
\hline Customs exemption & For raw materials and machinery for export-oriented manufacturers \\
\hline
\end{tabular}

Source: General Incentive, MIDA 2002.

The Malaysian government also holds down the relative prices of investment goods. In 1994, the Malaysian Federal Government has eliminated tariff on some 600 items including machines and machinery part, and electrical and electronic equipment. In 1995 federal budget also eliminated tariffs on over 2600 additional items include tariff reductions on 1400 industrial raw materials plus some other durable and non-durable goods. With the realization of AFTA in 2003, all barriers to trade will be eliminated among ASEAN countries, including non-tariff restrictions. Reduction of tariff between 0 to 5 per cent for all products is expected to encourage trade within the region. Even before the full realization of AFTA in 2003, many multinational companies have begun looking at the ten ASEAN countries as a single entity and shifting their investments, looking for the best possible approach to gain market advantage.

\subsection{General Overview of Foreign Investment in Malaysia}

FDI flows, wages, dividends, interest, and rental income earned in Malaysia were exempted from controls and has a fairly long history. As early as 1920 s, there was already substantial British investment in the country. It has been government policy to encourage FDI into the country since Malaysia got her independence in 1957. Postindependence era marked a drastic shift in the structure of foreign investment in the high-tech industries. By 1980, foreign ownership of the Malaysian corporate sector had declined to 47.5 per cent (Arif \& Mohamed, 1991). According to the World Bank, Malaysia was one of the top five recipients of FDI in the developing world during 
1987-1991 (DFAT, 1995). Malaysia has been a recipient of large inflows of foreign investment. In 1990, Malaysia accounted for 16 per cent of all foreign investment inflows to the Asian Pacific region, while Thailand accounted for 13 per cent (World Bank, 1993).

However, foreign investments continue to play a very important role in the Malaysian economy. It was part of the government policy to restrict foreign equity into the country, but government very much interested that foreign firms enter into joint ventures with local partner. Following a series of relaxation, in May 2001 the government completely eliminated one of the most controversial of the selected controls when it abolished a $10 \%$ tax on profits by foreign investors on portfolio investments taken out of the country.

\subsection{Bilateral Investment Agreements}

In the process of attracting FDI, bilateral investment agreement plays a minor role in investment development. Both developing and developed countries, which have presented their needs have been considered and taken in the investment agreement. Since the Bilateral Investment Agreement existed, Malaysia has signed an agreements with 51 countries and country groupings. Malaysian guarantee agreement with United Stated is controlled under the U.S overseas Private Investment Corporation (OPIC) program. The Malaysia's government adopts guarantee agreement with other country continuously in different year. Ministry of International Trade and Industry has informed the objective of the trade mission was to further enhance existing bilateral trade relations and economic cooperation between Malaysia and Australia (MATRADE, 2001).

TABLE 8: Malaysia's Bilateral Investment Agreement

\begin{tabular}{|c|c|c|c|}
\hline Year & Country & Year & Country \\
\hline 1959 & United Stated of America & 1985 & Austria, Finland \\
\hline 1960 & Germany & 1987 & Organization of Islamic Conference, Kuwait, ASEAN \\
\hline 1971 & Canada & 1988 & Italy, South Korea, People's Republic of China \\
\hline 1972 & Netherlands & 1991 & United Arab Emirates \\
\hline 1975 & France & 1992 & Denmark, Vietnam, Papua New Guinea, Chile, Laos \\
\hline 1978 & Switzerland & 1993 & Taiwan, Hungary, Poland \\
\hline 1979 & $\begin{array}{l}\text { Sweden, Belgium and } \\
\text { Luxembourg }\end{array}$ & 1994 & $\begin{array}{l}\text { Indonesia, Albania, Zimbabwe, Turkmenistan, Namibia, Cambodia, } \\
\text { Argentina, Jordan, Bangladesh, Croatia, Bosnia-Herzegovina }\end{array}$ \\
\hline 1981 & United Kingdom & 1995 & Spain, Pakistan, Kyrgyz, Mongolia, Uruguay, India \\
\hline 1982 & Sri Lanka, Romania & 1996 & Peru, Kazakhstan, Malawi, The Czech Republic \\
\hline 1984 & Norway & 1997 & Egypt \\
\hline
\end{tabular}

Source: Government of Malaysia, 1997

\subsection{Foreign Capital}

In general, saving and investment have obvious significance as determinants of long-run growth. In Malaysia, the behavior of savings and investment are equally important in explaining the performance of the overall economy of the country. To attract the needed foreign capital, the government has established various legal and bureaucratic mechanisms within the framework of the national development plans (Abu Samah \& Hamzah, 1976). Malaysia has also established bilateral investment guarantee agreement with 51 countries and country grouping (see table 8).

The Malaysian government as well as the government of Indonesia and Thailand responded by restoring macroeconomic imbalance and within such framework, created incentives for export oriented, the FDI dependent industrialization. These domestic policy initiatives were supported by influential financial institutions such as World Bank and IMF and coincided happily with the burst of Japan and NIE-led FDI that followed the exchange rate realignments of the mid 1980s. In 1980s and 1990s, the Malaysian government has undertaken drastic macroeconomic policies. 
TABLE 9: Basic Macroeconomic Indicators Of Malaysia, 1971-1999

\begin{tabular}{|l|c|c|c|c|c|c|c|}
\hline \multicolumn{1}{|c|}{ Indicators } & $\mathbf{1 9 7 1 - 8 0}$ & $\mathbf{1 9 8 1 - 9 0}$ & $\mathbf{1 9 9 2}$ & $\mathbf{1 9 9 4}$ & $\mathbf{1 9 9 6}$ & $\mathbf{1 9 9 8}$ & $\mathbf{1 9 9 9}$ \\
\hline Real GDP (\%) & 7.8 & 5.2 & 7.8 & 9.2 & 8.6 & -6.7 & -0.6 \\
\hline Growth rate Inflation rate (\%) & 6.0 & 3.2 & 4.7 & 3.7 & 3.5 & 5.3 & 5.9 \\
\hline Saving and investment \% of GDP & & & & & & & \\
Gross domestic investment & & 24.9 & 30.7 & 33.8 & 34.5 & 41.6 & 25.8 \\
Gross national savings & & 29.1 & 33.0 & 35.5 & 33.0 & 36.7 & 38.8 \\
Current account & & $-1.2 \mathrm{a}$ & $-1.9 \mathrm{~b}$ & -3.7 & -6.2 & -4.8 & 13.0 \\
Debt service ratio & & $4.6 \mathrm{a}$ & $29.0 \mathrm{~b}$ & 6.3 & 5.0 & 8.5 & 6.6 \\
\hline
\end{tabular}

Source: Asian Development Outlook (various Issues) and IMF Staff Country Report No. 99/85.

Notes: a 1980; b 1985

\subsection{Investment Under National Economic Plans}

The government has taken an active role in the development and industrialization of the Malaysian economy. This includes significant state sector investment, a close alliance between government and the private business sector, privatizing state enterprises and a variety of policies and programs to bolster the economic status of the Malay and indigenous communities, commonly referred to as bumiputera.

Since independence, a series of national development plans have been formulated and implemented by the government. The main objective of these national economic plans was the economic growth. The government in October 1956 approved the first five-year plan (1956-1960). To attract foreign capital, the Malaysian government allows foreign investors to own 100 percent of the equity and provide various incentives through the legislation (Sundram, J. K., 1986). The first major legislation on such incentives was the 1958 Pioneer Industries Ordinance, which was designed to encourage both foreign and domestic investment.

The second five-year Malaya Plan (1961-1965) was also formulated with IBRD assistance. First, an improvement in the rural standard living, second the provision of greater employment opportunities and a faster rate of economic growth rate, third the diversification of agricultural and industrial activities and forth, an expansion of social overhead facilities (Lim \& David, 1982). The main strategy of this plan is income tax exemption, tariffs protection, the provision of industrial credit and industrial estates (Johns, B. L., 1975). The Federal Industrial Development Authority (FIDA) was established in 1965 to coordinate all matters relating to industrial development.

The First Malaysia Plan (1966- 1970) emphasized import substitution industries and resource processing for export. However, as the domestic market limited further growth in this type of project, manufacturing for export gradually absorbed more of foreign capital allocation by reducing the role of import-substitution projects from almost 29 per cent of approvals in the Third Malaysian Plans.

\subsection{Background of the New Economic Policy (NEP)}

The New Economic Policy (NEP) in Malaysia was one of the measures adopted by the government to achieve the objectives of national unity, and to improve the relative and absolute standard of living of Malays. The NEP was designed over a period of twenty-year Perspective Plan of 1970-1990, which was incorporated into the formal development plans. The Investment Incentives Act of 1971 was replaced in 1986 with a new Promotion of Investment Act (PIA), which to provide incentives for manufacturing, agriculture, and tourism.

The Industrial Coordination Act of 1984 was amended again in 1987 to further liberalize regulative measures. The exemption limit for licensing was increased from $\$ 1$ million of shareholders funds or 50-fulltime employees in 1984 to $\$ 2.5$ million or 75 fulltime employees in 1987. In 1986, the government launched an aggressive privatization program, which led it to play a progressively diminishing role as a producer of goods and services. However, the government holds large equity stakes (generally minority shares) in a wide range of domestic companies. As part of the National Economic Recovery Plan (NERP) launched in the midst of the 1997-98 
economic downturn, the government has assisted a number of troubled corporations, primarily those identified as involving national or strategic interests or equity considerations under the New Economic Policy (NEP) and National Development Policy (NDP). Industries that have received, or are likely to receive, government assistance, include telecommunications, urban infrastructure, transportation, and steel.

Best prospects include agricultural products, defense-related procurement, and exports targeted at major government projects and infrastructure development. Opportunities will remain in priority areas of development, including high technology fields related to the MSC, industrial automation to enhance productivity, medical products and services, education/distance learning and environmental engineering.

\subsection{Seven Malaysian Plan (7MP)}

The macroeconomic goals in the Seventh Malaysian Plan (1996-2000) are sustaining high level of growth with price stability and enhancing the country's international competitiveness. The key strategic priorities of 7MP are human resource development, capital deepening, technology improvement, and capacity building (ADB, 1997).

The attractiveness of tax incentives, the appreciation of the Japanese Yen since 1985, the erosion of comparative advantage in labor intensive manufacturing in the NICs and acquisition activities of multinational corporations, contributed to a large inflow of investment to Malaysia, Thailand and Indonesia, where wages are lower (Legar, 1995). Malaysia's policy of wooing foreign investment through a combination of attractive incentive packages and the provision of infrastructure support in the export-processing zones has been extremely successful in attracting multinationals.

Japanese investment alone, increase from less than RM \$500 million in 1980 to RM \$4.2 billion in 1990. In 1989, Japan was the largest foreign investor in Malaysia, which contributed 31.1 percent of total foreign investment, followed by Taiwan 24.7 percent and Singapore 10.6 percent (D. Tsuruoka, 1990). In the first nine-month of 1994, the Ministry of International Trade and Industry (MITI) approved 457 projects with foreign investment components of US \$9.61 million, compared with 390 projects worth US \$3.23 million in the corresponding period of 1993 . Besides attracting FDI into the country, the government also at the same time encouraged the Malaysian to make overseas investment. For that purpose in 1993 the Malaysian government has established Trade Development Corporation (TDC), a statutory board responsible to attract local investors to invest in foreign countries.

FDI rather than short-term private sector borrowings and other portfolio investment have dominated foreign capital inflows to Malaysia over the past ten years. However prior to the onset of the financial crisis, there was a significant increase in the inflow of private short-term capital. Under the NEP, the Bumiputera share of corporate sector equity has increase from 4.3 per cent in 1971 to 19.4 percent in 1988 . The foreigners have fallen from 61.7 per cent to 24.6 percent over the same period.

Most countries have liberalized their investment regimes, and many provide costly fiscal incentives in the expectation of the multiple benefits that are typically associated with FDI. Foreign direct investors are believed to increase domestic capital formation to augment host country stocks of technology and managerial know how, and to improve excess to export markets and to a comparatively stable source of external financing. Therefore, Malaysia have fine statements about the need for increasing productivity, competitiveness, and increasing Total Factor Productivity in Malaysian Vision 2020, 7th Malaysia Plan and the Second Industrial Master Plan (1996-2005).

\subsection{Second Industrial Master Plan (1996-2005)}

To remain as an attractive investment destination, Malaysian economic expert and policy makers together to adjust and improve trade policy to be more attractive in Second Industrial Master Plan. The plan was covered how Malaysia faced with the financial and economic downturn problem, and the government's further initiatives to attract FDI in Malaysia in particular by the year 2003 with the fully implementation of the ASEAN Free Trade Area (AFTA) between ASEAN region. 
To ensure Malaysia's competitiveness in the global economy, the government has made modifications to the current policy on equity for the manufacturing sector and give a direct effect on flexibility in the equity holdings of local and foreign investors.

\subsection{Conclusion}

The prospects for Malaysian economic growth in 2002 are very much depends on domestic activities. However the outlook of the external sector remains uncertain, particularly in the light of the aftermath of the September 11 incident. Government policies to "open her door" and undertake outward-looking strategies have contributed to a rapid growth of export and inward oriented FDI. Trade liberalization policies have also substantially changed the pattern of savings and investment. In this globalization era, the government has been aggressively adopted new fiscal policy to further strengthen domestic demand and boost the economic growth.

Economic development in Malaysia can be seen as a variant of the Solow model, in which savings, investment and capital accumulation are the major agents of growth. In the case of Malaysia, the availability of technology is a necessary but not a sufficient condition for the transition from the agricultural to low-and high-tech industrial stage. The rate of savings and investment must also be high. In turn, government policy to increase FDI into the country was and is desirable. One aspect of the fast factor accumulation in this country is the important of FDI flows as a source of technology and management skills. FDI vis a vis savings and investment may have triggered export competitiveness by improving the technology, management and marketing of export industries.

Economic integration through foreign and domestic investment into this country has sustained economic growth of Malaysian economy. Malaysian economy experts believe foreign investors will continue to play a main role in the Malaysian economy. However beyond 2010, the domestic investors will dominate the domestic investment and able to compete with foreign investors at home and in global business (Sivalingam, G., 2000). The Malaysian condition as an attractive location for foreign investment becomes a gateway to the country into global markets.

In the era of globalization, Malaysia is expected to promote economic growth through greater volumes of trade and enlarge domestic and foreign investment. Other strategies that ensure the foreign investors get what they are looking for in Malaysia have also been given due attention. These include strategies for sustainable economic growth, stability, adequate infrastructure, physical goods and information flows, skilled workers with continuous training facilities, good financial and legal systems.

\section{References}

1. Abu Samah, \& Hamzah. "Industrial Development and Opportunities for Investment," Malaysian Management Review, 11, 2 August 1976, p.18.

2. Adam, Christopher \& William, C., "Background," in Jomo K. S. ed., Privatizing Malaysia: Rents, Rhetoric, Realities, London: West view Press, 1995.

3. Arif, Mohamad, "The Malaysian Economy: Pacific Connection", Oxford University Press, Kuala Lumpur, 1991.

4. $\quad$ Asian Development Bank (ADB), News release No. 153/96, December 5, 1996.

5. $\quad$ Asian Development Bank (ADB), News Release No. 24/99, 19 April 1999.

6. Chandravarker, A. "Savings behavior in the Asian-Pacific region". Asian Pacific Economic Literature, May 1993, 1:9-27.

7. $\quad$ Clifford, M. L., "Can Malaysia Take That Next Big Step?", McGraw-Hill, Kuala Lumpur, 1997.

8. $\quad$ Daily Express, "Malaysia Boosts Prospects for Higher Investments", Kuala Lumpur, April 2, 2002.

9. DFAT. Country Economic Brief, Malaysia, Department of Foreign Affairs and Trade, Government of Australia, January, 1995.

10. Economic Planning Unit, "Seventh Malaysia Plan 1996-2000", EPU, Kuala Lumpur, 1996.

11. Economic Report, "Malaysia Economy: First Quarterly Report of 2002", Kuala Lumpur, March 8, 2001.

12. Government of Malaysia, Government Publication, 1997 
13. Hassan, Parvez, 'Growth, Structural change, and Social Progress,' in Malaysia: Growth and Equity in a Multiracial Society, ed., Young, Kevin; Bussink, W. C. F.,; Hassan Parvez, The Johns Hopkins University Press, 1980.

14. Holloway N., 'The new NICs,' Far Eastern Economic Review, 28 February 1991, p.72.

15. International Monetary Fund, "Malaysia: Statistical Appendix", IMF, Washington, 2001.

16. Johns, B. L. "Import Substitution and Export Potential: The Case of Manufacturing Industry in West Malaysia”. In Reading on Malaysian Economic Development. Ed. David Lim. Kuala Lumpur: Oxford University Press, 1975, pp $156-71$.

17. Kasper, Wolfgang, Malaysia: A Study in Successful Economic Development (Washington, D.C.: American Enterprise Institute for Public Policy Research, 1974. pp. 14 - 17.

18. Lim, David. "Malaysian Development Planning." Pacific Affairs. 55, 4 (Winter, 1982 - 83): pp. 613 - 39.

19. Malaysia: Investment Climate Statement, "Openness to foreign investment", September 3, 1999 URL: http://merkury.saic.com/ts/partners/baytrade.html

20. MATRADE, access on April 4, 2002. URL: http://www.matrade.gov.my MIDA, "Review of the Industrial Master Plan 1996-2005", Kuala Lumpur, 1996.

21. Ministry of International Trade and Industry, "Malaysia's Individual Action Plan Summary", accessed on April 13, 2002 URL: http://miti.gov.my/apec1998/miap97

22. Ministry of International Trade and Industry WebPages, accessed on March 23, 2002 URL: http://www.miti.gov.my

23. Prospect for 2002, "The Outlook of the External Sector in 2002 Remain Uncertain", accessed on January 18, 2002 URL: http://www.smpke.jpm.my/NewSMPKE/economy/prospects.htm

24. Public Bank Economic Review, 2002.

25. Radelet, S., Sachs, J., \& Jong-Wha Lee, "Economic Growth in Asia", Harvard Institute for International Development, November 1997 URL: http://www2.cid.harvard.edu/hiidpapers/ecgasia.pdf

26. Schoenberg, H. O., "Globalization Offers Unstable Ground for Foreign Investors", Earth Times News, United Nation, December 21, 2000

27. Sieh Lee Mei Ling, "Taking on the World: Globalization Strategies in Malaysia", McGraw-Hill, Kuala Lumpur, 2000.

28. Sivalingam, G., "The Impact of Globalization on the Malaysian Economy", Foreign Affairs, p.79-93, February 7, 2000

29. Stephen Leong, "How to Achieve Domestic and International Economic Stability: A Malaysian Perspective", Institute of Strategic and International Studies (ISIS) Malaysia, Tokyo, 7 February 2000

30. Solow, Robert M., "A Contribution to the Theory of Economic Growth," Quarterly Journal of Economics, 1956, 70(1): $65-94$.

31. Sundaram, J. K., "Interests and Accounting Standard Setting in Malaysia: Using a Political Economy of Accounting (PEA) Framework", 1996. URL: hhtp://les.man.ac.uk/ipa97/papers/susela81.pdf

32. World Bank, World Bank Report, Pamphlet, 1993, p. 4. 